\title{
SEXISM IN EFL TEXTBOOKS USED IN INDONESIAN SCHOOLS
}

\author{
Syarifuddin
}

Email: syarifuddin12@gmail.com

Universitas Yudharta Pasuruan

\begin{abstract}
Since English is a compulsory subject in Indonesian schools where students have to use certain EFL textbooks, examining sexism in these textbooks is important. This study examined sexism in three of the most widely used EFL textbooks in Indonesian schools. Six criteria of sexism were used in analysing the data, namely: generic he; generic man; titles, labels and names; occupational roles both in texts and pictures/ illustrations; omission, the number of females and males both in texts and pictures/ illustrations; and firstness, the order of mention. The analysis was based on the National Council of Teachers of English (NCTE)'s 'Guidelines for gender-fair use of Language' (2002) and Porecca's study (1984). In all criteria of sexism, there is evidence that sexism is present in the EFL textbooks used in Indonesian schools. The most unbalanced and the worst finding is the firstness (the order of mentions) with the ratio 10:1 in favour of male gendered words that appear first. This study suggests that there should be improvement in the production of the EFL textbooks used in Indonesian schools.
\end{abstract}

Keywords: EFL, Sexism, textbook

\section{INTRODUCTION}

Sexism in English textbooks has been discussed for more than three decades (e.g. Hartman \& Judd, 1978; Amare, 2007). Studies of sexism found that many English textbooks or materials present unnecessarily stereotyped portrayals of males and females. The findings suggest that females are disadvantaged in the textbooks (e.g. Hartman \& Judd, 1978; Hellinger, 1980: Porecca, 1984; Dickman \& Murnen, 2004). In Indonesia, since English is compulsory subject in all level of schools, and school students have to use certain EFL textbooks which are recommended by the Ministry of National Education and Culture, analysing and examining sexism in these textbooks is important because textbooks have an impact on learners' construction on how they see gender identities (e.g. Martyna, 1978; Hellinger, 1980; Sakita, 1995). Textbooks also give students models and attitudes through the portrayal of females and males. If the models, for example, are stereotypical, unequal, biased, or disadvantaged for one gender, students can do similar things in their real life. As Hartman and Judd (1978) argue that when sexism is taught through ESL texts to students, they may use that sexism in their life. Therefore, Hartman and Judd (1978) suggest that controlling English textbooks is needed because 'change will come too slowly unless we make an effort to further it' ( $\mathrm{p}$. 392). There has been no study of sexism in EFL textbooks used in Indonesian school. Thus, this study looks at sexism in EFL textbooks used in Indonesian schools.

\section{Sexism}

Sexism is defined by Cameron (1985) as 'a system in which women and men are not simply different, but unequal. Sexism in language is manifestation of the system, and it works to the disadvantage of women, not men' (p. 100-101). In sexism, linguistic scholars often used another specific term such as sexist language (e.g. Graci, 1989; Parks \& Robertson, 2000; Dickman \& Murnen, 2004; Lei, 2006) or linguistic sexism (e.g. Amare, 2007). Both terms have the same 
meaning, but the term sexist language is more often used by scholars. Lei (2006) defines sexist language as 'language that expresses bias in favour of one sex and thus treats the other sex in a discriminatory manner. In most cases the bias is in favour of men and against women' (p. 87). From those terms, it can be said that sexist language is under the umbrella of sexism. An example of sexism in language is 'every student should bring his textbook'. This sentence should be 'every student should bring his/her textbook.

The discussion of sexism in English textbooks was initiated by Hartman and Judd (1978) in 'Sexism and TESOL materials.' They examined ESL textbooks from American and British publications published within the previous 12 years. Their study (1978) examined 'the use of the word man both as an independent word and as a bound suffix, the generic he, the boy/girl distinction, and titles used refer to men and women' (p. 383). They found that TESOL materials reflected sexism in attitudes and values. The worst finding is the ratio of males to females that appears in TESOL materials which was 73 to 27 percent (approximately 3:1). After Hartman and Judy's study (1978), many studies in sexism appeared. For example, Porreca (1984) in 'Sexism in current ESL textbooks', she examined 15 ESL textbooks used in the US. She states that 'sexism continues to flourish in EFL materials' (p. 718). Porreca (1984) examined sexism in 'the categories of omission in text and illustration, firstness, occupational visibility in text and illustrations, nouns, masculine generic constructions, and adjectives' (p. 705). In terms of the design or the procedure, this study (Porreca, 1984) is better than Hartman and Judd's study (1978). The procedure of Porecca's study (1984) is more systematic by discussing one-by-one of categories of sexism. In addition, Hartman and Judd (1978) analysed arbitrary sample of textbooks and they did not mention how many textbooks they analysed, whereas Porecca (1984) examined 15 current ESL textbooks which used in 27 different ESL centres.

Another study which is different from the previous studies which analysed sexism on printed texts is Amare (2007) who examined seven online grammar guides which focused on 'generic he and man; titles, labels, and names; gender stereotypes; order of mention (firstness); and ratio of male and female (p. 163). Unlike Porreca's study (1984), Amare's study (2007) focused only on linguistic sexism. In other words, pictures, images and illustrations were not included. Also, these online grammar guides were analysed based on National Council of Teachers of English's (2002) (hereafter NCTE) 'Guidelines for gender-fair use of Language' which made this study different from the previous ones. In selecting online websites, Amare (2007) chose seven .edu websites of colleges and universities from different regions which provided sufficient sentences that can be printed. The findings of this study are similar to other studies. The study shows that there is linguistic sexism especially on firstness and male-to-male ratio in online grammar guides.

\section{Aspects of sexism in textbook studies}

English textbook studies have found sexism in many different aspects. One of the most widely analysed aspects of sexism is generic he and generic man (also called masculine generic constructions). This problem actually comes from the grammar of English itself which some words such as man, mankind refer to people in general both males and females (Porecca, 1984). So, it is not surprising that some studies (e.g. Miller \& Swift, 1976; Clason, 2006) revealed that some people are confused about masculine generic constructions. A study by Moulton, Robinson and Elias (1978) revealed that when students were asked to write an essay, most of students were found to use generic he or his which referred to males only although they were asked to write such male terms to be gender neutral which include females. Other studies of generic he (e.g. Martyna, 1978; Silveira, 1980) also found similar findings.

Similarly, there is also confusion and objection in the use of generic man in some occupational and positional titles such as chairman, policeman, fireman, salesman, etc. (e.g. Hartman \& Judd, 1978; Amare, 2007). In this case of masculine generic constructions, Moulton et. al (1978) argue that '[m]ales may have an advantage in their coming more readily to mind in context when they are referred to by a putative neutral term' ( $p$. 1032). Regarding to this, many institutions 
and linguists have tried to provide guidelines to avoid sexist language such as Committee of Equality of Opportunity (1994), NCTE (2002), Peters (2004) and including some scholars, for example, Mills (2003) encourages the use of gender fair alternatives, and Mitchell (1994) encourages the use of they as singular pronoun to avoid the use of exclusionary generic he (e.g., a good student has to pay attention to their teachers, rather than a good student has to pay attention to his teachers). However, some learners may dislike this format because it looks illogic (Madson \& Hessling, 1999) and also some opponents argue that this grammar is incorrect (e.g. Kearns, Walker, McCoy, \& Balhorn, 1994).

Another aspect of sexism that is also usually discussed is 'titles, labels and names' (NCTE, 2002, p. 4). Studies have found exclusionary words and phrases in titles, labels and names such as stewardess, authoress, male nurse, lady lawyer, old maid, Miss, Mrs, lady pitcher, etc (e.g. Hartman \& Judd, 1978; Amare. 2007) which have to be avoided. In this aspect, NCTE (2002) suggests to '[i]dentify men and women in the same way,...[s]eek alternatives to language that omits patronizes, or trivializes women,...(and) [u]se courtesy titles that pronounce gender equity' (p. 4-5). The examples above should be steward or fight attendant, author, nurse, lawyer, single person, Ms, and pitcher (NCTE, 2002, p. 4-5). However, in some cases, 'if the gender of a personal is important to a person seeking professional assistance, exceptions may occur.... i.e. a male who is a nurse rather than male nurse.' (NCTE, 2002, p. 5).

Occupational role is also one aspect of sexism that is often examined. It is easy to find studies that reported the imbalance of occupational roles between males and females in textbooks. Studies found that the roles for males in the textbooks varied such as doctor, pilot, school principal, ambassador, professor, store manager etc., while the roles for females are limited such as bank employee, salesgirl, house wife, nurse, etc. (e.g. Hartman and Judd, 1978). A similar study by Hellinger (1980) analysed 131 passages of three English textbooks used in German schools and found that in the passages women were seldom to have professional jobs; only two of women had professional jobs, while men had a various interesting occupations. It is also found in studies that females are often, if not always, represented as weak, passive, overemotional and superficial whereas males are represented as strong, active, helpful and patronising (e.g. Porecca, 1984; Amare, 2007). In addition, Hartman and Judd (1978) conclude that 'women are far less visible than men in occupational roles' (p. 719). These studies suggest than women look passive, less valuable or less competent. As Amare (2007) states that ' $[\mathrm{w}]$ omen were still stereotyped as passive, and the focus of these sentences was on women's physical attributes' (p. 180).

Occupational role is another aspect of sexism that is often examined. It is easy to find studies that reported the imbalance of occupational roles between males and females in textbooks. Studies found that the roles for males in the textbooks varied such as doctor, pilot, school principal, ambassador, professor, store manager etc., while the roles for females are limited such as bank employee, salesgirl, house wife, nurse, etc. (e.g. Hartman and Judd, 1978). A similar study by Hellinger (1980) analysed 131 passages of three English textbooks used in German schools and found that in the passages women were seldom to have professional jobs; only two of women had professional jobs, while men had a variety different interesting occupations. It is also found in studies that females are often, if not always, represented as weak, passive, overemotional and superficial whereas males are represented as strong, active, helpful and patronising (e.g. Porecca, 1984; Amare, 2007). In addition, Hartman and Judd (1978) conclude that 'women are far less visible than men in occupational roles' (p. 719). These studies suggest than women look passive, less valuable or less competent. As Amare (2007) states that ' $[\mathrm{w}]$ omen were still stereotyped as passive, and the focus of these sentences was on women's physical attributes' (p. 180).

Next criterion that is also widely discussed in sexism is the number of males and females in the textbooks/materials. This criterion is also known as omission (Porecca, 1984). It is often found in textbook studies that men outnumber women in textbooks while there are more women in this world than men. As Graham (1975, cited in Porecca, 
1984, p. 707) found that 'although there are actually more women then men in the real world, these textbooks contained over seven times as many as women.' A study by Hellinger (1980) found that men appeared in more than 93 percent in 131 passages from three ESL textbooks and a third of the passages did not included females. Porecca (1984) found similar occurrences of omission; 'the average ratio of females to males in the text is 1:1.77' and 'the mean proportion of females to males in illustration is $1: 1.97^{\prime}$ (p. 713-714). Similar studies by Sakita (1995) and Amare (2007) found the same. These studies suggest that females seem less important. As Porecca (1984) states that ' $[\mathrm{w}]$ hen females do not appear as often as males in the text..., the implicit message is that women's accomplishment, or that they themselves as human beings are not important enough to be included' (p. 706).

Order of mention is the sixth criterion in which one of genders (males or females) is presented first. This is also known as firstness (Porecca, 1984). Many studies revealed that males often came first compared to females such as father and mother, brother and sister, with the exception of ladies and gentlemen (e.g. Hartman \& Judd, 1978). Porecca (1984) also found the same finding in her study that 'the average ratio of female to male firstness is $1: 2.96$ ' (p. 714). Amare's study (2007) in firstness is even worse than Porecca; the ratio of male to female firstness is almost 5:1. These studies again suggest that females were found less important than males. In this case, Hartman and Judd (1978) suggest ' $[\mathrm{w}]$ hile this may be a minor point, such automatic ordering reinforces the second-place status of women and could, with only a little effort, be avoided by mixing the order' (p. 390).

The discussion of previous studies above shows that sexism still exists in English materials. Nielsen (1988) even argued that there is lack effect of "Guidelines for Nonsexist Use of Language, 1985" on the treatment of gender in business writing textbooks. However, it is believed that sexism can disappear if society does not facilitate sexism in every aspect of life including in textbooks. As the Committee of Equality of Opportunity (1994) states that, 'language is not static. It is constantly changing to reflect the changing nature of society. As we are moving towards equality in all areas of life, it is important that our language facilitate and reflect this change' (p. 1). Moreover, although some scholars argue that there is no clear and sufficient method to asses EFL/ESL textbooks in sexism (e.g. Graci, 1989; Sokolik, 2007), a lot of efforts have been made by feminists and linguists to reinvent grammatical rules and to make guidelines for gender-fair use of language to avoid linguistic sexism or sexist language (e.g. Cameron, 1985; Miller \& Swift, 1988; the Committee of Equality of Opportunity, 1994; Parks \& Robertson, 2000; NCTE, 2002). Not only feminists and linguists, but most style manual books also have particular chapters that discuss sexism such as 'Inclusive treatment of the sexes' in The Oxford guide to style (Ritter, 2002, p. 58-60), 'sexism' in Style manual for authors, editors and printers (AusInfo, 2002, p. 105-106), etc.

In Indonesia, as discussed in introduction, since English is compulsory subject in all level of schools, and school students have to use certain EFL textbooks, a study of analysing sexism in EFL textbooks used in Indonesia is important. To date, as far as I know, no research or examination on EFL textbooks used in Indonesian schools. So, this is the topic of this study. This study focused only on EFL textbooks used in Indonesian schools and written by Indonesian authors. It did not include Indonesian universities EFL textbooks which are imported, written and published by native speakers of English. The aim of this study is to look at sexism in EFL textbooks used in Indonesian schools and then determine the status of sexism in EFL textbooks used in Indonesian schools. So the research question of this study is "Is sexism present in EFL textbooks used in Indonesian schools?"

Sexism in this study, based on scholars' definition (e.g. Brittan \& Maynard, 1984; Cameron, 1985; Lei, 2006), is defined as lexicon, grammatical rules of English or pictures/illustration that 'exclude, insult or trivialise' (Cameron, 1985, p. 101) one gender. In other words, sexism is defined as language or pictures/illustration that expresses one gender is more superior, more competent, or more valuable than another one. One of the expected outcomes of this study is for suggesting authors or textbook 
stakeholders to have awareness in producing textbooks, in this case of this study, EFL textbooks in Indonesia. In other words, if sexism is present in EFL textbooks used in Indonesian schools, it will be evident that there should be a room for improvement in producing the next EFL textbooks in Indonesia. Because women in Indonesia today have the same rights and equality, there should be fair and accurate portrayals or stereotyped images of women in EFL textbooks.

\section{METHODOLOGY}

This study is a text-based analysis of sexism in EFL textbooks used in Indonesian schools (elementary, junior and senior high schools). This study analysed and examined three of the most widely used EFL textbooks in Indonesian schools: (1) Let's go with English 1 which is for the first year of elementary school; (2) English on sky 1 which is for the first year of junior high school; and (3) Look ahead which is for the first year of senior high school. See Table 1.

Table 1. The EFL textbooks used in Indonesian schools

\begin{tabular}{|l|l|}
\hline Year & Textbooks \\
\hline $\begin{array}{l}\text { Year 1 (elementary } \\
\text { school) }\end{array}$ & $\begin{array}{l}\text { Kurniawan, R., Rachmadi, A.S. \& Hidayat, D. A. 2007. Let's go with English } \\
\text { 1. Bogor: Yudhistira. }\end{array}$ \\
\hline $\begin{array}{l}\text { Year 7 (junior high } \\
\text { school) }\end{array}$ & $\begin{array}{l}\text { Mukarto, M., Sujatmiko, S., Muwarni, J. S. \& Kismara, W. 2007. English on } \\
\text { sky 1 for junior high school students year VII. Jakarta: Erlangga. }\end{array}$ \\
\hline $\begin{array}{l}\text { Year 10 (senior high } \\
\text { school) }\end{array}$ & $\begin{array}{l}\text { Sudarwati, T. M. \& Grace, A. 2007. Look ahead: An English course for } \\
\text { senior high school students year X. Jakarta: Erlangga. }\end{array}$ \\
\hline
\end{tabular}

Six different criteria of sexism were analysed in this study: (1) generic he; (2) generic man; (3) titles, labels, and names; (4) occupational roles for males and females, both in texts and illustrations or pictures; (5) omission, the number of females and males in texts and illustrations or pictures; and (6) firstness (the order of mention) between females and males (see table 2 for more detail). The analysis of the first three (1-3) is based on National Council of Teachers of English (NCTE)'s 'Guidelines for gender-fair use of Language' (2002), and the analysis of the rest (4-6) is based on Porecca's study (1984). In general, the analysis is slightly similar to Amare's study (2007) with the exception of number 4 (occupational roles). However, this study is different from Amare's (2007) because this study does not only examine examples of sentences in grammar exercises, but also the whole materials (reading, writing, speaking, listening, etc.) including illustrations or pictures in the EFL textbooks used in Indonesian schools.

Table 2. Criteria for Analysing Sexism ${ }^{1}$

\begin{tabular}{|l|l|l|}
\hline No & Criteria & Explanation \\
\hline 1 & Generic $h e$ & $\begin{array}{l}\text { The male singular pronoun used as the default pronoun to } \\
\text { represent both genders, e.g., If a student studies hard, he will } \\
\text { succeed. }\end{array}$ \\
\hline 2 & Generic man & $\begin{array}{l}\text { The use of man to represent both genders excludes women, } \\
\text { e.g., mankind, chairman, businessman, etc. }\end{array}$ \\
\hline 3 & Ttles, labels, and names & $\begin{array}{l}\text { The use of linguistically feminized words and titles, e.g., } \\
\text { stewardess, ballerina, authoress, Miss, lady lawyer, etc. }\end{array}$ \\
\hline 4 & Occupational roles & $\begin{array}{l}\text { The number and the ratio of different occupations for } \\
\text { women and men both in texts (based on contexts) and } \\
\text { illustrations/pictures. }\end{array}$ \\
\hline 5 & Omission & $\begin{array}{l}\text { The number and the ratio of females and males in both texts } \\
\text { and illustrations/pictures. }\end{array}$ \\
\hline 6 & Firstness & $\begin{array}{l}\text { The number and the ratio of order of mention (words pairs } \\
\text { of opposites genders), e.g., brothers and sisters, ladies and }\end{array}$ \\
\hline
\end{tabular}

1 taken and adapted from Porecca (1984, p. 712-713), NCTE (2002, p. 1-6), and Amare (2007, p. 171) 
gentlemen, he and she, etc.

\section{FINDINGS AND DISCUSSION}

The analysis of three textbooks is presented below based on the six criteria that have been

discussed in the methodology and in the Table 2.

Generic he
Only few examples of the generic he were found. Indeed, there is no example of the generic he in Let's go with English 1. This is because this textbook, which is for six or seven years-old students, does not have many sentences; there are more pictures or illustrations than sentences. In English on sky 1 , one generic he is found, and, three cases of generic he were found in Look ahead. See Table 3 below for more details.

Table 3. The numbers and examples of generic he

\begin{tabular}{|l|l|l|}
\hline Textbooks & $\begin{array}{l}\text { Numbers of } \\
\text { generic he }\end{array}$ & Examples \\
\hline $\begin{array}{l}\text { Let's go with } \\
\text { English 1 }\end{array}$ & 0 & - \\
\hline English on sky 1 & 1 & $\begin{array}{l}\text { Describe the person to your friend and let him guess who } \\
\text { the person is (p. 164) }\end{array}$ \\
\hline Look ahead 1 & 3 & $\begin{array}{l}\text { - Tell your friend... you can't see the manager because he } \\
\text { is not here today (p. 9). } \\
\text { You are a personal manager. Give a compliment to one } \\
\text { of your staff on his work and you want to raise his salary } \\
\text { (p. 130). [all italics added] }\end{array}$ \\
\hline
\end{tabular}

Based on NCTE (2002), the examples in the Table 3 above should use the singular they/their/them form, for example, 'Describe the person to your friend and let them guess who the person is.' However, although, as NCTE (2002) argues, 'this construction is becoming increasingly acceptable' (p. 3) teachers should explain to their students that this construction may be incorrect in exams. Regarding to this, NCTE (2002) suggests other alternative constructions or forms that can be used. For example, by using both a male and a female pronoun together, 'Describe the person to your friend and let him/her (her/him) guess who the person is.' Other sentences could be 'Give a compliment to one of your staff on his/her work and you want to raise her/his salary' [all italics added]. By using different order of pronouns such as his/her and her/his, the sentences also have avoided the unbalanced firstness (the order of mention), which is another sexism category that will be discussed later in this study.

\section{Generic man}

As in the case of generic he, there is no example of generic man found in Let's go with English 1. However, there are 17 examples found in the other two textbooks. An example that is found in Look ahead 1 is, 'Work in groups. 'Suppose your class was going to choose a class chairman' (p. 134) [all italics added]. This example shows that this sentence ignores the existence of female students in the class. Also, the use of man in chairman must be avoided by replacing it, as NCTE (2002) suggests, with 'chair, coordinator, moderator, presiding officer, head, [or] chairperson' (p. 4). Other examples of generic man that were found are shown in Table 4.

Based on NCTE (2002), the examples of the use man in describing jobs could be avoided. They should be business person, post officer, craft worker, police officer, athlete, moderator, business executive, spokesperson, etc. NCTE (2002) also suggests avoiding the gender specific term in describing jobs or careers including these for women such as chairwoman, businesswoman, congresswoman, 
policewoman, etc. Regarding to this, there are two examples that were found in Look ahead 1 and no examples were found in the other two textbooks. Those examples are: 'Role play. Work in pairs. One student will be Mrs. Andrews and the other student a policeman/policewoman.' (p. 119) and '... she would make an excellent class chairwoman' (p. 134) [all italics added]. The authors could use police officer and chairperson instead of policeman/policewoman and chairwoman.

Table 4. The numbers and examples of generic man

\begin{tabular}{|l|l|l|}
\hline Textbooks & $\begin{array}{l}\text { Numbers of } \\
\text { Generic man }\end{array}$ & Some examples \\
\hline $\begin{array}{l}\text { Let's go with } \\
\text { English 1 }\end{array}$ & 0 & - \\
\hline English on sky 1 & 3 & businessman (p. 85; p. 89), postman (p. 89) \\
\hline Look ahead 1 & 14 & $\begin{array}{l}\text { craftsman (p. 32), policeman (p. 79), postman (p. 95), } \\
\text { sportsman (p. 126), chairman (p. 134), businessman (p. } \\
\text { 185), spokesman (p. 187), etc. }\end{array}$ \\
\hline
\end{tabular}

\section{Titles, labels, and names}

In the criteria of titles, labels and names, many examples of Miss were found especially in English on sky 1, and many examples of Mrs were found particularly in Look ahead 1 (see Table 5 for more details). Even the authors of Look ahead explain about the differences between Miss, Mrs and Ms. Here is the explanation, 'Miss - for young girls $>29$, Ms - for unmarried women $>30$, Mrs for all married woman...' (p. 6). This shows that the textbooks do not pay very much attention to the current use of titles in English. Based on NCTE (2002), it is better to avoid forms such as Miss, Mrs and choose Ms to 'create an equitable form of address for all women regardless of marital status. Use $M s$. for married as well as unmarried women' ( $p$. 6).
Many interesting examples of Mrs are found in Look ahead by using tittles that label a woman in regard to her husband. One example is, "The chairman and director of General Mercantile Ltd requests the presence of Mr. \& Mrs. Frank Jackson to the opening ceremony of the branch office of General Mercantile....' (p. 152) [all italics added]. This example shows sexism and it could be avoided by replacing $M r s$ with $M s$ and replacing a woman's name before her husband's name. The sentence, as NCTE (2002) suggests, could be 'The chair person and director of General Mercantile Ltd requests the presence of Ms (her name) Jackson and Mr. Frank Jackson to the opening ceremony of the branch office of General Mercantile.'

Table 5. The numbers and examples of titles, labels, and names

\begin{tabular}{|l|l|l|}
\hline Textbooks & $\begin{array}{l}\text { Numbers of } \\
\text { titles, labels, } \\
\text { and names }\end{array}$ & Some examples \\
\hline $\begin{array}{l}\text { Let's go with } \\
\text { English 1 }\end{array}$ & 1 & Miss Ani (p. 12) \\
\hline $\begin{array}{l}\text { English on sky } \\
1\end{array}$ & 68 & $\begin{array}{l}\text { Miss Ina (p. 4), Miss Imelda (p. 53), Mrs Samuel (p. 89), } \\
\text { stewardess (p. 86), waitress (p. 89), actress (p. 172), etc. }\end{array}$ \\
\hline Look ahead 1 & 26 & $\begin{array}{l}\text { Mrs Nina (p. 4), Mrs Subagya (p.29), Miss Suzuki (p. 54), } \\
\text { princess (p.59), Mrs Shelly (p. 65), Mrs Lina (p. 65), Mrs } \\
\text { Forester (p. 109), Mrs Andrews (p. 119), Mrs, Ana Karaeng } \\
\text { (p. 133), Mrs Trim (p. 134), Mrs Frank Jackson (p. 152), } \\
\text { etc. }\end{array}$ \\
\hline
\end{tabular}




\section{Occupational roles}

In all the textbooks, occupational roles for men are more varied, and the number of occupations for men also outnumbers women's occupations (55:16) (see Table 6 for more details). The ratio of women's occupations to men's occupations in this study is 1:3.44. In Let's go with English 1, occupations between women and men is very unequal. The ratio is 1:9. This is the worst ratio of occupational roles in this study. In this textbook, most pictures or illustrations of females are passive; females seem to be mainly at home. For example, except as a teacher, females are illustrated only as ones who take care of their children (p. 10), make a cake (p. 59), carry a baby (p.63), prepare meals for family (p.63; p. 68), water flowers (p. 67), go to markets to buy daily food (p. 73 ), etc. On the other hand, males are illustrated as active people, for example, going to an office wearing a tie and bringing a formal bag (p. 10; p. 16), riding motorcycle (p. 64), doing sports (p. 50; p. 56; p. 67; p. 102), accompanying children to the zoo without their mothers (p. 98), etc.

In English on sky 1, although women's occupations are more varied than the other two textbooks, the number of women's occupations is only half of men's occupations (not including the occupations for both women and men). The occupations for women are only 12 , whereas the occupations for males are 24 (see Table 6 for more details). An interesting example to note in English on sky 1 (p. 52) is that the occupation of school principal, which is often lead by men, is for women, and in contrast, the occupation of vice principal is for man. However, the context and the provided picture of this occupation (school principal) shows stereotyping; when Shanti ask to Rahmad Hidayat (the vice principal) who is standing beside Ms Hidayati (the school principal), 'Are you school principal, sir?' Then Rahmad Hidayat answers 'Oh, no. I am not. I'm the vice principal....this is Ms Budiarti, the school principal' (p. 52) [all italics are added]. This example shows clearly that school principal is stereotyped as men occupation. Many occupations that were found English on sky 1 are also stereotyped as men's occupations such as army officer, security guard, architect, logger, engineer, mechanic, etc.

Table 6. The occupational roles in the texts and pictures/illustrations

\begin{tabular}{|c|c|c|c|}
\hline \multirow{2}{*}{ Textbooks } & \multicolumn{3}{|l|}{ Occupational roles } \\
\hline & Women only & Men only & Women \& Men \\
\hline $\begin{array}{l}\text { Let's go } \\
\text { with } \\
\text { English } 1\end{array}$ & Housewife (1) & $\begin{array}{l}\text { Police officer, director, } \\
\text { manager, army, newspaper } \\
\text { seller, fruit seller, farmer, } \\
\text { cook and clown (9) }\end{array}$ & Teacher (1) \\
\hline $\begin{array}{l}\text { English on } \\
\text { sky } 1\end{array}$ & $\begin{array}{lr}\text { School } & \text { consular, } \\
\text { Indonesian } & \text { teacher, } \\
\text { civics teacher, religion } & \text { school } \\
\text { teacher, r } & \text { principal, secretary, } \\
\text { dentist, doctor, cook, } \\
\text { designer, musician } \\
\text { and writer (12) }\end{array}$ & $\begin{array}{l}\text { Science teacher, vice } \\
\text { principal, physical } \\
\text { educational teacher, art } \\
\text { teacher, police officer, } \\
\text { footballer, sailor, mechanic, } \\
\text { driver, cashier, security } \\
\text { guard, programmer, scientist, } \\
\text { architects, business person, } \\
\text { engineer, golfer, soldier, } \\
\text { watchmaker, racer, army } \\
\text { officer, logger, scout and } \\
\text { comedian (24) }\end{array}$ & $\begin{array}{l}\text { Teacher, } \\
\text { presenter, } \\
\text { assistant, civil servant, } \\
\text { artist, editor, farmer, } \\
\text { swimmer, reporter, } \\
\text { singer and dancer } \\
(11)\end{array}$ \\
\hline $\begin{array}{l}\text { Look ahead } \\
1\end{array}$ & $\begin{array}{l}\text { Prostitute, } r \text { flight } \\
\text { attendant and model } \\
(3)\end{array}$ & $\begin{array}{l}\text { Editor, footballer, guitarist, } \\
\text { scientist, chemist, professor, } \\
\text { president, painter, craftsman, } \\
\text { secretary, driver, postman, } \\
\text { sportsman, }\end{array}$ & $\begin{array}{lr}\text { Teacher, } & \text { singer, } \\
\text { writer, } & \text { doctor, } \\
\text { presenter, } & \\
\text { newsreader, artist, } \\
\text { police officer and }\end{array}$ \\
\hline
\end{tabular}




\begin{tabular}{|l|l|l|l|}
\hline & $\begin{array}{l}\text { headmaster, guide, journalist, } \\
\text { businessman, spokesman, } \\
\text { lawyer, supervisor and } \\
\text { minister (22) }\end{array}$ & \\
\hline
\end{tabular}

Similar to English on sky 1, in Look ahead 1 many occupations are also stereotyped as men's occupations such as president, professor, minister, scientist, chemist, etc. The worst example of women's occupation that was noticed in Look ahead 1 is prostitute. Even the textbook repeats this occupation twice in two different chapters but using the same reading material (taken from Jakarta Post), 'Prostitute Mongkon Pusuwan, 37, was charged with drug trafficking last month, an offense carrying a caning punishment for males' (p. 27; p. 181) [all italics added]. Beside the case of prostitute, the sentence itself also indicates sexism by showing the readers that someone who was doing drug trafficking was a woman. In terms of the ratio of occupations in Look ahead 1, for each occupation for women, there are seven occupations for men (1:7). Based on the numbers of occupational roles and the ratio in this study, this finding certainly shows that there is sexism in the EFL textbooks used in Indonesian schools, and it is similar to what Porecca's finding (1984) that 'women are far less visible than men in occupational roles' (p. 719).

\section{Omission}

Using the concept of mission, which is defined by Porecca (1984) as the number of females and males appear in texts and illustrations and pictures, is complex but interesting. The results reveal that the number of males both in texts and in the pictures or illustrations outnumbers the number of females with the exception of the omission in English on sky 1. See Table 7 below for more details.

Table 7. The omission in the texts and pictures/illustrations

\begin{tabular}{lllll}
\hline \multirow{2}{*}{ Textbooks } & Omission & & \multicolumn{2}{l}{ Pictures/illustrations } \\
& $\begin{array}{l}\text { texts } \\
\text { Males }\end{array}$ & Females & Males & Females \\
\hline Let's go with English 1 & 76 & 75 & 250 & 154 \\
English on sky 1 & 771 & 848 & 251 & 310 \\
Look ahead 1 & 1259 & 968 & 85 & 36 \\
\hline Total & 2106 & 1891 & 586 & 500 \\
\hline
\end{tabular}

In Let's go with English 1, the numbers of males and females in texts is equal (76:75). This number is the most balanced or equal number in omission, whereas the number of males in illustrations or pictures is almost double to the females' number (250:154). It is also interesting to note that in Let's go with English 1, there are 10 chapters and each chapter consists of five parts. They are listen, speak, read, write and mini dictionary. In all these parts, the authors provide a male picture only, except in the part of speak which shows pictures of a male and a female. This evidence seems to indicate that males are suggested to be more active than females in all macro skills (listening, reading and writing skills) except speaking skill. In other words, Let's go with English 1 seems to ignore female students in all skills other than speaking skill and it also shows stereotyping of female students in favour of speaking skill rather than the other three skills.

In English on sky 1, surprisingly the number of females both in text and pictures or illustrations outnumbers the males' number. This is the only finding that contrasts from the other textbooks (see Table 7 for more details). However, it does not mean that the omission in English on sky 1 is good because the unbalanced number also shows sexism although it is against men. As Amare (2007) argues that although sexism is often against women, sexism that is against men is also dangerous. In Look ahead 1, the number of pictures or illustrations of males is more than double compared to the females' number (85:36).This the most unbalanced number of omission in this study with the 
ratio 2.36:1. This finding is similar to Hartman and Judd's study (1978) which had the approximate ratio 3:1 (73:27).

Besides, putting only male pictures at the cover pages of the textbooks such as in English on sky 1 and Look ahead 1 is not a good idea and it does show sexism. Also, putting only male pictures at the cover pages looks to show that male students are more important and more active than female students. It is also shows that textbooks seem only for male students, whereas in fact there are more female students in the classroom (Depdiknas, 2008). ${ }^{2}$ In total, as shown in the table 7 , if all results are combined, males still outnumber females (2692:2391). This number is slightly similar to Amare's study (2007) which had 1807 males and 1021 females. These findings of omission both in texts and pictures or illustrations show that

2 For example, in senior high schools in Indonesia the number of male students in 2008 is $1,798,045$, whereas the number of female students is $1,960,848$. there is sexism in the EFL textbooks used in Indonesian schools.

\section{Firstness}

The result of firsness is the worst result or the most unbalanced number in this study compared to the other five criteria of sexism above. There are 70 examples of male gendered words that come first before female gendered words, while only seven examples of female gendered words appear before male gendered words (see Table 8 for more details). In Let's go with English 1, 13 examples of firstness are found but none of them in favour of female gendered words that come first. In English on sky 1, 34 examples in firstness are found but only one female gendered word appears first, so the ratio is 33:1. In Look ahead 1, the are 30 examples of firstness that are found. Only six female gendered words come first including two examples of ladies and gentlemen so the ratio is $4: 1$.

Table 8. The numbers and examples of firstness (the order of mention)

\begin{tabular}{|c|c|c|c|}
\hline \multirow[t]{2}{*}{ Textbooks } & \multicolumn{2}{|c|}{$\begin{array}{l}\text { Numbers of } \\
\text { firstness }\end{array}$} & \multirow[t]{2}{*}{ Some examples } \\
\hline & M first & F first & \\
\hline $\begin{array}{l}\text { Let's go with } \\
\text { English } 1\end{array}$ & 13 & 0 & $\begin{array}{l}\text { - good morning boys good morning girls (p. 12); } \\
\text { - he is my father and she is my mother (p.64), etc. }\end{array}$ \\
\hline $\begin{array}{l}\text { English on } \\
\text { sky } 1\end{array}$ & 33 & 1 & $\begin{array}{l}\text { - How many (brothers) or sisters do you have? (p. 80). } \\
\text { - Ask five students about their father's/ mother's jobs } \\
\text { (p. 92). } \\
\text { - Write a letter to him/her describing yourself (p. 173). }\end{array}$ \\
\hline $\begin{array}{l}\text { Look ahead } \\
1\end{array}$ & 24 & 6 & $\begin{array}{l}\text { - He or she will life forever. He or she will never die (p. } \\
\text { 44). } \\
\text { - If anyone declines an offer, try offering him/her } \\
\text { something else (p. 66). } \\
\text { - Jim and Della began to think what present they could } \\
\text { afford to give each other (p. 106). etc. [all italics } \\
\text { added] }\end{array}$ \\
\hline
\end{tabular}

Overall, the ratio of firstness in this study is 10:1 in favour of male gendered words that appear first. This means that male words were mentioned before female words 10 times more often than female words were mentioned first. This finding of the firstness clearly indicates sexism. This finding is also worse than previous findings. For example, Porecca (1984) revealed in her study that 'the average ratio of female to male firstness is 1:2.96' (p. 714) and Amare (2007) found that the ratio of firstness in her study is almost 5:1 in favour to male words.

\section{CONCLUSION}

This study examined sexism in the EFL textbooks used in Indonesian schools. In all criteria of sexism in this study, there is evidence, based on the findings and the discussion above, that sexism is present in the textbooks used in Indonesian schools. Four examples of the generic he, 17 examples 
of the generic man, and 95 examples of titles, labels and names that show sexism were found. The findings of the occupational roles in this study both in the numbers and the variation of occupations between women and men are also unbalanced. The ratio of occupations between women and men is $1: 3.44$. The number of males and females (omission) both in texts and pictures or illustrations in this study also shows unbalanced numbers although it is slightly better than previous studies. The most unbalanced and the worst finding in this study is the firstness or the order of mentions with the ratio 10:1 in favour to male gendered words. Overall, the findings of this study are similar to previous studies (e.g. Hartman \& Judd, 1978; Porecca, 1984; Amare, 2007).

Although this study provides useful information to the understanding of sexism in the textbooks, particularly in the EFL textbooks used in Indonesian schools, this study is far from perfect. Three EFL textbooks are relatively small number of textbooks.
Thus, further research with more textbooks is needed. This study also only examined sexism in the EFL textbooks. Further research in attitude of teachers and students regarding to sexism in EFL textbooks is also needed.

The findings of this study have pedagogical implication for the government or the Ministry of National Education since the recommendation of the use of EFL textbooks is on the government's decision. This study suggests, based on the findings of this study, that the authors or stakeholders of EFL textbooks should be aware of the existence of sexism in the EFL textbooks. This means that there should be improvement in the production of the next EFL textbooks used in Indonesian schools. Another pedagogical implication is for teachers who use EFL textbooks. Teachers should be aware in the use of EFL textbooks because textbooks give students models and attitudes, if the textbooks show sexism which is stereotypical or biased or disadvantaged for one gendered students as this study, students may use that sexism in their life (Hartman \& Judd, 1978).

\section{REFERENCES}

Amare, N. 2007. Where is she? Gender occurrences in online grammar guides. Research in the Teaching of English, 42(2), 163-187.

AusInfo 2002. Style manual for authors, editors and printers. Canberra: AusInfo.

Brittan, A. \& Maynard, M. 1984. Sexism, racism and oppression. New York: Blackwell.

Cameron, D. 1985. Feminism and linguistic theory. New York: St. Martin's Press.

Clason, M. 2006. Feminism, generic 'he' and the TNVI bible translation debate. Critical Discourse Studies, 3(1), 33-35

Committee of Equality of Opportunity. 1994. Non-sexist language: A guide. Retrieved 26 March, 2010, from, http://www.ucc.ie/equalcom/language.html

Depdiknas. 2008. Number of pupils by sex, status of school and province. Retrieved April 2, 2010, from http://www.depdiknas.go.id/statistik/0708/sma_0708/tbl_13.pdf

Dickman, A. B. \& Murnen, S. K. 2004. Learning to be little women and little men: The inequitable gender equality of non sexist children's literature. Sex Roles, 50, 373-385.

Graci, J. P. 1989. Are foreign language textbooks sexist? An exploration of models of evaluation. Foreign Language Annals, 22(5), 477-486. 
Graham, A. 1975. The making of non-sexist dictionary. In B. Thorne \& N. Henley (Eds.), Language and sex, (pp. 57-63). Rowley Massachusetts: Newbury House Publishers.

Hartman, P. L \& Judd, E. L. 1978. Sexism and TESOL materials. TESOL Quarterly, 12(4), 383-393.

Hellinger, M. 1980. For men must work, and women must weep: sexism in English language textbook used in German schools. In Cherish K. (Ed), The voices and words of women and men. (pp. 267-274). New York: Pergamon Press.

Kearns, E. A., Walker, M., McCoy, K. \& Balhorn, M. 1994. Four comments on "The politics of grammar handbooks: Generic he and singular they." College English, 56, 471-477.

Lei, X. 2006. Sexism in language. Journal of Language and Linguistics, 5(1), 87-94.

Madson, L. \& Hessling, R. M. 1999. Does alternating between masculine and feminine pronouns eliminate perceived gender bias in text? Sex Roles, 41, 559-575.

Martyna, W. 1978. What does "he" mean? Use of the generic masculine. Journal of Communication, 28(1), 131-138.

Miller, C. \& Swift, K. 1976. Words and women. Garden City, NY: Anchor Press.

Miller, C. \& Swift, K. 1988. The handbook of non-sexist writing (2nd ed). New York: Harper \& Row.

Mills, S. 2003. Caught between sexism, anti-sexism, and 'political correctness': Feminist women negotiation with naming practices. Discourse \& Society, 14, 87-110.

Mitchell, F. 1994. Student writing and pronoun reference: a study of inclusive language in practice. Women and Language, 17, 2-5.

Moulton, J., Robinson, J. M. \& Elias, C. 1978. Sex bias in language use: “neutral” pronouns that aren't. American Psychologist, 33(11), 1032-1036.

National Council of Teachers of English. 2002. Guidelines for gender-fair use of language. Retrieved February 17, 2010, from http://www.ncte.org/positions/statements/genderfairuseoflang

Nielsen, E. 1988. Linguistic sexism in business writing textbooks. Journal of Advanced Composition, $8,55-65$.

Parks, J, B. \& Robertson, M. A. 2000. Development and validation of an instrument to measure attitudes towards sexist/non-sexist language. Sex Roles, 42, 415-438.

Peters, P. 2004. The Cambridge guide to English usage. Cambridge: Cambridge University Press.

Porreca, K. 1984. Sexism in current ESL textbooks. TESOL Quarterly, 18(4), 705-724.

Ritter, R. 2002. The Oxford guide to style. Oxford: Oxford University Press.

Sakita, T. I. 1995. Sexism in Japanese English education: a survey of EFL texts. Women and Language,17. 5-12.

Silveira, J. 1980. Generic masculine words and thinking. In Cherish K. (Ed), The voices and words of women and men. (pp. 267-274). New York: Pergamon Press. 
Sokolik, M. E. 2007. Grammar Texts and Consumerist Subtexts. TESL-EJ: The Electric Journal of English as Second Language, 11(2), 1-9. Retrieved March 3, 2010, from http://www.cc.kyotosu.ac.jp/information/tesl-ej/ej42/a6.pdf 